J. Amer. Soc. Hort. Sci. 115(1):20-24. 1990.

\title{
Antitranspirant Reduces Water Use by Peach Trees Following Harvest
}

\author{
Susan L. Steinberg and Marshall J. McFarland \\ Department of Agricultural Engineering Texas A\&M University, College Station, TX 77843 \\ Josiah W. Worthington \\ Texas A\&M University Agricultural Research and Extension Center, Stephenville, TX 76401 \\ Additional index words. lysimeter, transpiration, Prunus persica, growth rate
}

\begin{abstract}
The potential for reducing water use of peach [Prunus persica (L.) Batsch] trees with antitranspirants following fruit harvest was investigated using matched peach trees planted in an outdoor twin weighing lysimeter facility. A $\mathbf{1 0 \%}$ solution of the antitranspirant Wilt Pruf NCF was applied to one of the two trees on 7 July 1986. Immediately after application, water use of the treated tree was reduced by $40 \%$. One month after treatment, the water use was reduced $30 \%$ and, by the termination of the experiment ( 85 days after treatment), water use was reduced $12 \%$ as compared to control. The average reduction in tree water use for the entire period was $30 \%$. Fully expanded, sunlit leaves (nodes 10 to 20 from the terminal end) from the treated tree exhibited the greatest reduction in water loss compared with immature or inner canopy, shaded leaves. Use of the antitranspirant did not prevent the development of water stress once a critical level of soil moisture was reached. The change in tree water use induced by the antitranspirant did not significantly reduce shoot length, new leaf production, or individual leaf size on actively growing, current-season branches. Fruit and leaf bud initiation, as measured the following spring, were not affected: however. flower bud maturation could not be evaluated due to freeze damage. Chemical name used: di1-p-menthene (Wilt Pruf NCF).
\end{abstract}

Antitranspirants have been used on a variety of tree crops to improve tree water potential (Davenport et al., 1972, 1974a) or reduce tree water use (Davenport et al., 1974b). Film-forming antitranspirants add additional resistance to the water loss pathway by partially covering or blocking stomata (Davenport et al., 1972; Gale and Hagan, 1966; Solarova et al., 1981). A concurrent reduction in photosynthesis may occur, depending on permeability of the film to $\mathrm{CO}_{2}$, which is often one-fourth that for water vapor (Davies and Kozlowski, 1974). The effect of antitranspirants on the maintenance or growth of woody plant organs depends on the sensitivity of growth to an improved tree water status vs. a possible reduction in photosynthate supply, the season of the growth period, and the availability of stored carbohydrates (Davenport et al., 1972, 1974a; Chalmers et al., 1983). For example, antitranspirants promoted an increase in internode length and leaf elongation in oleander (Davenport et al., 1974a), but no increase in shoot length was reported for apple (Weller and Ferree, 1978).

The duration and effectiveness of antitranspirants varies with environmental and plant conditions. Davies and Kozlowski (1974) reported water use reductions for up to 30 days on Pinus and Fraxinus spp. In oleander, water loss was reduced to $10 \%$ of the control 3 weeks after antitranspirant application (Davenport et al., 1973). Olive trees treated with an antitranspirant had higher fruit and leaf water potentials than nontreated trees for up to 1 month after application (Davenport et al., 1975). However, it is difficult to determine the maximum duration of antitranspirant effectiveness from these studies, as experimental periods were often terminated before total loss of effectiveness was observed.

Our study was designed and conducted to evaluate the effectiveness of an antitranspirant on water relations of peach trees

\footnotetext{
Received for publication 7 Dec. 1988. Texas Agricultural Experiment Station Technical Article 24282. Mention of trade names is for the convenience of the reader and does not constitute endorsement by the Texas Agricultural Experiment Station. The cost of publishing this paper was defrayed in part by the payment of page charges. Under postal regulations, this paper therefore must be hereby marked advertisement solely to indicate this fact.
}

following harvest, with specific emphasis on the magnitude and duration of tree water use reduction, manifestations of this reduction in terms of tree water status, and the effect on longterm vegetative growth.

\section{Materials and Methods}

This study was conducted at the twin weighing lysimeter facility at the Texas A\&M Univ. Agricultural Research and Extension Center, Stephenville, during Summer 1986. Each lysimeter contained a 4-year-old tree ('Sentinel' on Nemaguard rootstock) planted in the topsoil of a Windthorst fine sandy loam (Typic udic paleustalfs). The two lysimeter trees were designated as either east or west lysimeter. Each lysimeter was $2.44 \mathrm{~m}$ in diameter and $1.52 \mathrm{~m}$ deep. The weighing mechanism consisted of three strain gauge load cells, with a weighing sensitivity of $1 \mathrm{~mm}$ of water over the surface area of the lysimeter, or $4.5 \mathrm{~kg}$ (McFarland et al., 1983).

A weather station at the lysimeter site contained sensors for solar radiation, temperature, relative humidity, and wind speed. Data from the lysimeter load cells and weather sensors were collected and processed by a Campbell Scientific CR21X datalogger (Logan, Utah).

On 7 July 1986 [calendar day number (CDN) 188], the peach tree in the east lysimeter (AT) was sprayed to drip point with a $10 \%$ (v/v) solution of the antitranspirant Improved Wiltpruf NFC (Nursery Speciality Products, Greenwich, Corm.). The concentration was slightly higher than the commercially recommended application rate. The peach in the west lysimeter was the control (CT) tree. Water use of both trees was monitored throughout the remainder of the season.

During mid-July, the soil of both trees was allowed to dry simultaneously. After 8 days, leaves of both trees were wilted and the test was terminated. During this cycle, soil moisture measurements were made in both lysimeters by tensiometers set at a $0.3-\mathrm{m}$ depth and by neutron probe from $0.4-$ to $1.22-\mathrm{m}$ depths. There was one tensiometer and two neutron probe access tubes per lysimeter can. The soil volumetric water content was determined by calibrating the neutron probe for the lysimeter 
soil (Haverkamp et al., 1984; Van Bavel, 1963). At all other times, both trees were watered nightly to maintain well-watered conditions; the soil moisture potential never exceeded -0.03 $\mathrm{MPa}$ as measured by the tensiometers.

Twelve representative current-year branches per tree were tagged in June 1986. Branch elongation and leaf production rates were monitored throughout the summer. Two months after antitranspirant application, the leaf area of the 4th, 8th, 12th, etc. leaf on 15 similarly selected branches was measured with a LI-COR LI-3000 portable area meter (Lincoln, Neb.). Each branch had at least 34 leaves. Leaf and flower buds on 15 random branches per tree were counted during bud swell stage in Spring 1987.

Before and after application of the antitranspirant, leaf water potential $\left(\psi_{\mathrm{L}}\right)$ was measured with a pressure chamber on sunlit, fully expanded leaves from current and 1-year-old wood at 0600 HR and between 1300 and 1500 HR (Scholander et al., 1964). Leaf water potential measurements were replicated five to 10 times per tree. Transpiration and diffusive resistance were measured with a LI-COR LI-1600 Steady State Porometer during selected days on the 4th, 8th, 12th, etc. leaf from the terminal end along current and 1-year-old wood. Measurements on other days were made only on the 8th and 12th leaf from the terminal end. Transpiration and diffusive resistance readings were replicated on three to four branches per tree. Leaves at the 4th to 8 th node from the terminal end were generally unfolded but not completely expanded; leaves at the 8th to 20th node from the terminal end were fully expanded. Leaves at node 22 or higher were fully expanded, but shaded by the inner canopy of the tree.

Statistically significant differences $(P<0.05)$ in leaf water relations and growth measurements between the two trees were determined by Student's t test for comparison of two means (Steele and Torrie, 1980).

\section{Results}

The atmosphere was hot and dry throughout July, Aug., and most of Sept. 1986. Daytime means were 35C, the minimum relative humidity was $35 \%$ to $40 \%$, and wind speeds ranged from 4 to $10 \mathrm{~m} \cdot \mathrm{s}^{-1}$. Rainfall in July, August, and September was 31.5, 61.2, and $115 \mathrm{~mm}$, respectively. During the 3-month period, there were only two rainfall events with total precipitation $>25 \mathrm{~mm}$.

Water relations. Before antitranspirant application on CDN 188, the water use of both trees was similar, with neither tree using consistently more or less water than the other (Fig. 1). Immediately after application, water use of the AT tree was reduced by $40 \%$. For the first 30 days (CDN 189 to 219) after treatment, the reduction in water use was $30 \%$ and, by 70 to 85 days (CDN 259 to 273), water use was reduced 12\% compared to the control tree. The average reduction in water use for the entire period was $30 \%$ compared to the control tree.

During the 8-day dry-down cycle (CDN 189 to 197), the $40 \%$ difference in water use between the two trees remained constant, indicating that the antitranspirant was effective over the range of soil moistures imposed (Fig. 2). The diurnal cumulative water use of both trees is shown for a day at the beginning and end of the dry-down cycle (Fig. 3). The cumulative water-use pattern for the well-watered AT tree was similar to that of the dry CT tree. When the treated tree was allowed to dry, its water use was reduced to $=60 \%$ of the well-watered control tree.

Measurements of individual leaf transpiration rates confirm the whole-tree water-use pattern. Under well-watered conditions, the antitranspirant reduced transpiration rates at nodes 4
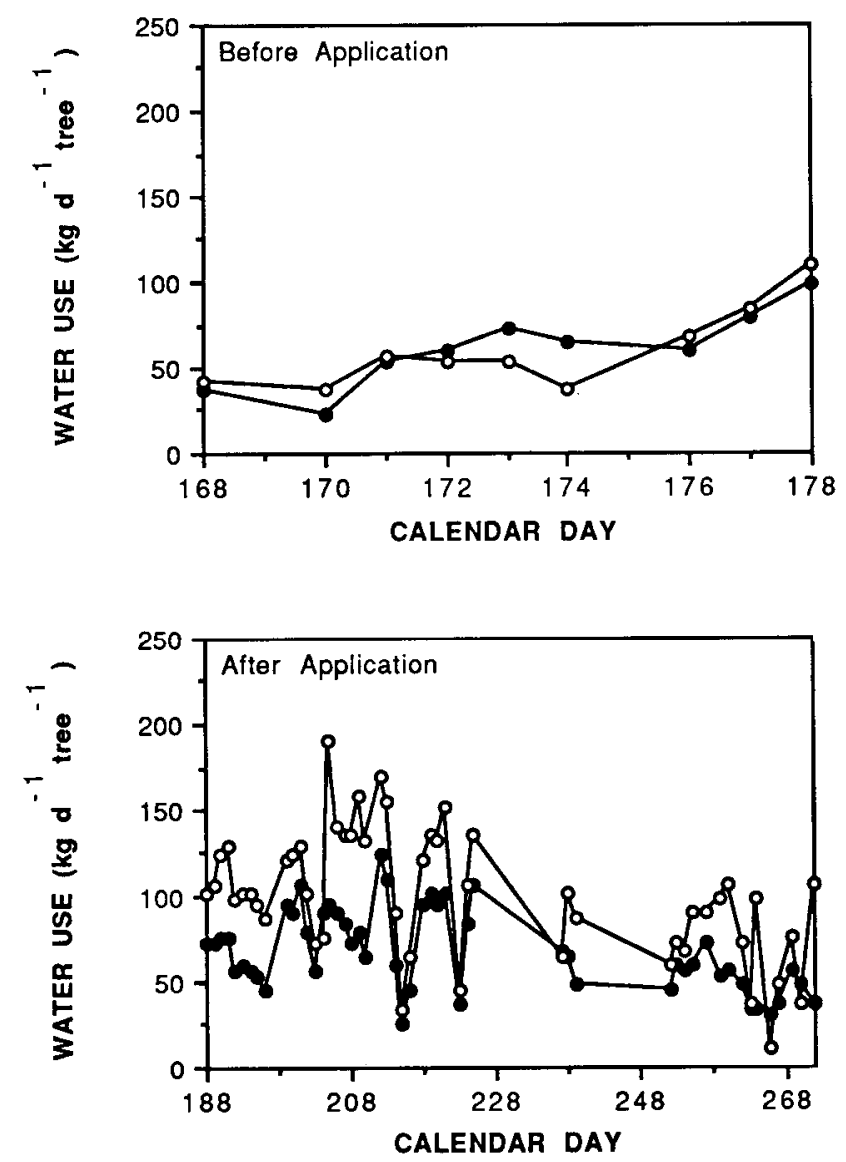

Fig. 1. Daily water use of the control ( $\bigcirc$ ) and antitranspirant $(\bigcirc)$ trees before and after application of the antitranspirant. Wiltpruf NFC was applied on CDN 188, 1986. The lysimeters were temporarily offline CDN 226-235 and 244-251.

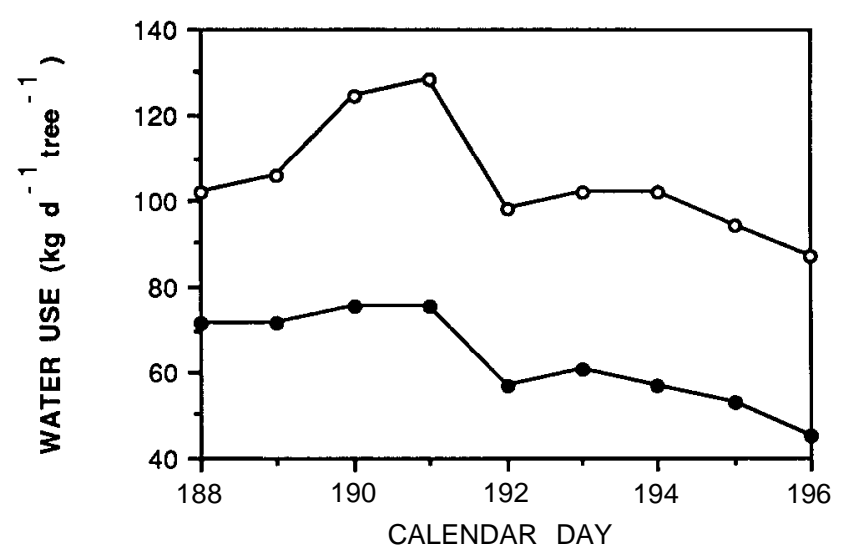

Fig. 2. Water use of the control ( $\bigcirc$ ) and antitranspirant ( $\bigcirc$ ) trees during a dry-down cycle.

to 24 along sunlit, current, and 1-year branches (Fig. 4). However, the reduction was greatest on fully expanded leaves midway on the branch (nodes 10 to 20) as compared with immature (nodes 1 to 6) or older, mature (greater than node 20) leaves. Early in the dry-down cycle, when the trees were still relatively well-watered (soil moisture potential was not less than -0.03 $\mathrm{MPa})$, transpiration from individual leaves was similar to that in Fig. 2. Leaves on the CT tree transpired at a higher rate than 


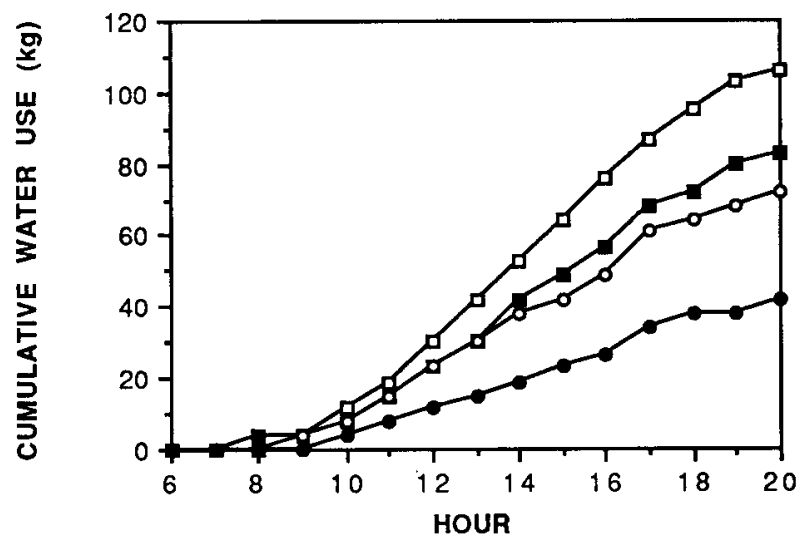

Fig. 3. Cumulative water use during 1-day periods when the trees were well-watered (CDN 189) and dry (CDN 196). Well-watered antitranspirant $(O)$ or control $(\square)$ tree; dry antitranspirant $(\bullet)$ or control (ם) tree.
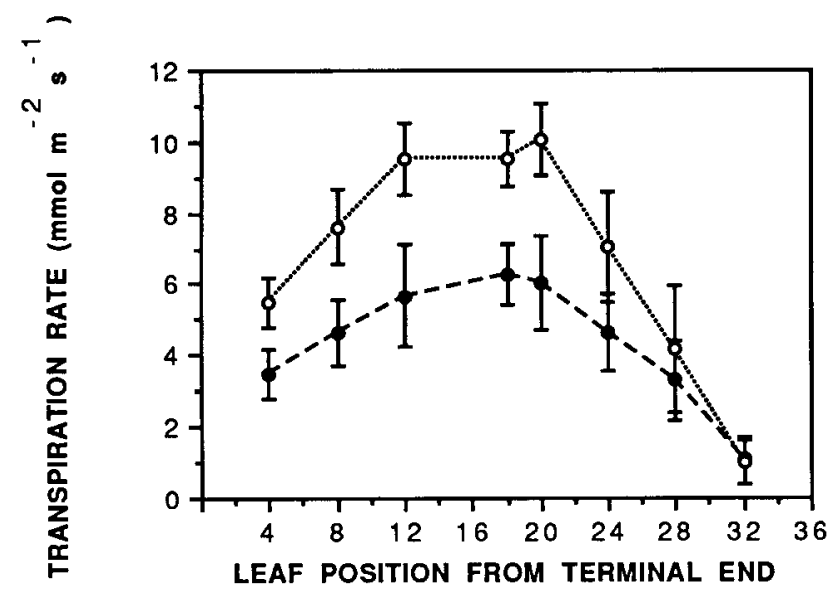

Fig. 4. Trarnspiration rate of leaves along sunlit, current and 1-yearold branches of the antitranspirant ( $\bullet$ ) and control ( $O$ ) trees. Both trees were well-watered on CDN 209. Data points and error bars represent the mean $\pm \mathrm{SE}$ from four separate branches per tree.

those on the AT tree (Table 1). Upon completion of the cycle, transpiration rates of leaves at all node positions measured were reduced, but CT transpiration rates were still greater than AT transpiration rates.

At the beginning of the dry-down cycle, soil moisture at 0.3 $\mathrm{m}$ was near field capacity in both lysimeters (Table 2). How- ever, due to the large soil volume $\left(7.1 \mathrm{~m}^{3}\right)$ it was difficult to ensure equal soil moisture at all depths in both lysimeters. In addition, the CT tree was using $40 \%$ more water, and thus drying the soil at a faster rate. To avoid the onset of severe water stress in the CT tree before the end of the dry-down cycle, it was irrigated with $378 \mathrm{~kg}$ of water during the night of CDN 189. However, this made the topsoil (upper $0.3 \mathrm{~m}$ ) wet for several days after watering, as indicated by the tensiometer readings. Soil moisture measurements obtained with the neutron probe in the upper $1 \mathrm{~m}$ of soil during the dry-down cycle indicated that the CT and AT trees reduced the volumetric water content by two-thirds and one-half, respectively. Below $1 \mathrm{~m}$, there was little evidence of water percolation from the irrigation on CDN 189. The control tree continued to use water at a similar rate and reduced the volumetric water content by half, while the AT tree extracted very little water from this depth, indicated by only a small change in the volumetric water content (from $25 \%$ to $20.2 \%$ ).

Leaf water potentials of both trees were not significantly different before application of the antitranspirant (Table 3). During the first few days of the dry-down cycle, which was also concurrent with the first several days after application of the antitranspirant, the mid-day $\psi_{\mathrm{L}}$ of the AT tree was only significantly higher than the CT tree on CDN 189. As the dry-down cycle progressed (CDN 193, 196, and 197) $\psi_{\mathrm{L}}$ of the tree was as low or lower than the CT tree. Even after normal watering had been resumed for at least 13 days (CDN 209 and 216), the AT tree still continued to have a $\psi_{\mathrm{L}}$ similar to, or lower than, the CT tree. Predawn values of $\psi_{\mathrm{L}}$ were similar for both trees.

Growth. Growth of current-year branches was evaluated by measuring branch elongation and new leaf production rates. Before antitranspirant application, the AT tree had a higher leaf production rate than the $\mathrm{CT}$ tree, but the branch elongation rate was not significantly different (Table 4). After application of the antitranspirant, the branch elongation and leaf production rate was not statistically different between trees.

The effect of the antitranspirant on final leaf size was examined by measuring the area of leaves along current-year branches. From branch elongation data, it was known that leaves younger than the 20th mature leaf from the terminal end were produced after antitranspirant was applied. Analysis of the average leaf area per leaf at four-leaf intervals from the terminal end (4th, 8th, 12th . . . 20th) showed no significant difference between the CT and AT trees (data not shown). The average area per leaf for all positions was likewise nonsignificant, both being $\approx 38 \mathrm{~cm}^{2} /$ leaf.

There was also no significant difference in leaf (20 to 23/ shoot) or flower bud count (10 to 12/shoot) between the AT and

Table 1. Transpiration rates of leaves at nodes 8 and 12 from the terminal end of branches from the antitranspirant (AT) and control (CT) trees at the beginning [calendar day number (CDN) 190] and end (CDN 196) of a dry-down cycle.

\begin{tabular}{|c|c|c|c|c|}
\hline \multirow{3}{*}{$\begin{array}{l}\text { Leaf position from } \\
\text { terminal end }{ }^{z}\end{array}$} & \multicolumn{4}{|c|}{$\begin{array}{l}\text { Transpiration rate } \\
\left(\mathrm{mmol} \cdot \mathrm{s}^{-1} \cdot \mathrm{m}^{-2}\right)\end{array}$} \\
\hline & \multicolumn{2}{|c|}{ CDN 190} & \multicolumn{2}{|c|}{ CDN 196} \\
\hline & AT & CT & $\mathrm{AT}$ & CT \\
\hline 8 & $2.73 \pm 0.42^{y}$ & $3.59 \pm 0.42$ & $1.35 \pm 0.20$ & $2.45 \pm 0.23$ \\
\hline 12 & $3.70 \pm 0.41$ & $5.00 \pm 0.83$ & $0.70 \pm 0.25$ & $2.29 \pm 0.26$ \\
\hline
\end{tabular}

${ }^{2}$ Measurements were made on sunlit leaves along current-year branches between 1300 and $1400 \mathrm{HR}$.

${ }^{y}$ Values are means $\pm \operatorname{SE}(n=8)$. 
Table 2. Soil moisture conditions of the control (CT) and antitranspirant (AT) trees at four depths during the dry-down cycle.

\begin{tabular}{|c|c|c|c|c|c|c|c|c|}
\hline \multirow[b]{3}{*}{ Calendar } & \multicolumn{2}{|c|}{$\begin{array}{l}\text { Tensiometer } \\
(\mathrm{MPa})\end{array}$} & \multicolumn{6}{|c|}{$\begin{array}{c}\text { Neutron probe } \\
\left(\% \mathrm{H}_{2} \mathrm{O} \text { by volume }\right)\end{array}$} \\
\hline & $\mathrm{CT}$ & $\mathrm{AT}$ & & $\mathrm{CT}$ & & & $\mathrm{AT}$ & \\
\hline & \multicolumn{2}{|c|}{ Soil depth (m) } & \multicolumn{6}{|c|}{ Soil depth (m) } \\
\hline day no. & 0.3 & 0.3 & 0.7 & 0.9 & 1.1 & 0.6 & 0.9 & 1.2 \\
\hline 189 & 0.012 & 0.012 & 11.6 & 15.0 & 19.0 & 14.6 & 18.4 & 25.0 \\
\hline $190^{\mathrm{Y}}$ & 0.030 & 0.021 & 24.7 & 22.9 & 20.5 & 13.9 & 17.9 & 24.9 \\
\hline 192 & 0.019 & 0.052 & 16.1 & 18.4 & 18.8 & 9.3 & 14.1 & 23.4 \\
\hline 193 & 0.020 & 0.064 & 14.4 & 16.6 & 18.2 & 8.6 & 13.0 & 22.4 \\
\hline 196 & 0.055 & 0.080 & 8.8 & 10.7 & 14.8 & 7.4 & 11.0 & 20.7 \\
\hline 197 & 0.060 & broke & 8.4 & 10.1 & 10.2 & 6.9 & 10.9 & 20.2 \\
\hline
\end{tabular}

${ }^{2}$ Average of two readings per depth

${ }^{\mathrm{Y}}$ Water added to CT only.

Table 3. Leaf water potential $\left(\psi_{L}\right)$ from the control (CT) and antitranspirant (AT) trees at solar noon and predawn. Antitranspirant was applied on CDN 188, 1986.

\begin{tabular}{llllll}
\hline & \multicolumn{5}{c}{$\psi_{L}(\mathrm{MPa})^{z, y}$} \\
\cline { 2 - 3 } \cline { 5 - 6 } $\begin{array}{l}\text { Calendar } \\
\text { day no. }\end{array}$ & \multicolumn{2}{c}{ Solar noon } & & \multicolumn{2}{c}{ Predawn } \\
\cline { 2 - 3 } \cline { 5 - 6 } $178^{\mathrm{x}}$ & -1.23 & -1.27 & & & $\mathrm{AT}$ \\
$189^{\mathrm{w}}$ & $-1.28^{*}$ & -1.59 & & \\
190 & -1.22 & -1.36 & & -0.28 & -0.24 \\
193 & $-1.64^{*}$ & -1.49 & & -0.40 & -0.37 \\
196 & $-2.22^{*}$ & -1.88 & & \\
197 & -2.19 & -2.10 & & -0.63 & -0.57 \\
$209^{v}$ & $-1.88^{*}$ & -1.65 & & & \\
216 & -1.28 & -1.23 & & \\
\hline
\end{tabular}

${ }^{z}$ Average of 10 or more measurements per tree.

$\mathrm{y}^{*}=t$ test comparing means from the AT and CT trees is significant at $P=0.05$.

${ }^{\times}$Before antitranspirant had been applied.

"Start of dry-down cycle.

"Normal watering resumed after termination of dry-down cycle.

Table 4. Effect of an antitranspirant on branch elongation and new leaf production rates of peach trees after fruit harvest.

\begin{tabular}{llllll}
\hline \hline & \multicolumn{2}{c}{$\begin{array}{c}\text { Branch } \begin{array}{c}\text { elongation } \\
\text { rate }\end{array} \\
\left(\mathrm{cm} \cdot \text { day }^{-1}\right)\end{array}$} & & \multicolumn{2}{c}{$\begin{array}{c}\text { New leaf production } \\
\text { rate } \\
\text { (leaves/day) }\end{array}$} \\
\cline { 2 - 3 } $\begin{array}{lllll}\text { Calendar } \\
\text { day no. }\end{array}$ & $\mathrm{AT}$ & $\mathrm{CT}$ & & $\mathrm{AT}$ & $\mathrm{c}-\mathrm{r}$ \\
\hline $167-178$ & 0.92 & 0.64 & & $0.82^{* z}$ & 0.66 \\
$188-216$ & 1.61 & 1.55 & & 0.93 & 0.93 \\
$216-278$ & 0.27 & 0.46 & & 0.21 & 0.34 \\
\hline
\end{tabular}

${ }^{\mathrm{I}}$ Indicates $\mathrm{t}$ test comparing means from treated (AT) and control (CT) trees is significant at $P=0.05$.

CT trees during bud swell stage the following spring (1987). A late spring freeze in 1987 destroyed the fruit crop for that year and no further measurements could be taken.

\section{Discussion}

One application of an antitranspirant reduced peach tree water use by 30\% during 3 months following harvest. Two rains occurred during this period, but they did not appear to remove the antitranspirant or reduce its effectiveness. This change in tree water use was reflected in lower transpiration rates of individual leaves. No significant reduction in vegetative growth, as measured by new leaf production and branch elongation, was observed. In addition, no differences were detected in the area per leaf, and fruit and leaf bud initiation at the bud swell stage between the AT and CT trees.

The results obtained for the effectiveness of an antitranspirant in reducing tree water use are generally consistent with other reports in the literature. A $30 \%$ to $40 \%$ reduction in water use has been reported for other woody species from soil water extraction (Gale and Hagan, 1966) and leaf transpiration (Davies and Kozlowski, 1974) data, and greenhouse pot studies (Davenport et al., 1973; Solarova et al., 1981). Weller and Ferree (1978) attributed short-lived (7- to 10-day) reductions in photosynthesis and transpiration rates of leaves from potted apple trees to stretching or cracking of the film by rapidly growing young leaves. The results of this study, conducted on fieldgrown trees in late summer when vegetative growth was slowing, are consistent with those of Albrigo (1977) and Davenport et al. (1974a), who showed a slow reduction in effectiveness over several months. Thus, antitranspirant studies performed on young woody plant seedlings may indicate antitranspirants to be less effective in water use reduction than shown here for a mature tree, due to a greater proportion of young growing leaves.

Of equal interest is the relationship between whole-tree water use and leaf water status. We show that the antitranspirant produced a maximal effect on fully expanded leaves. Jordan et al. (1975) and Kramer and Kozlowski (1979) have shown that stomata of mature, but not aged, leaves were most responsive to changes in plant water status. It has been suggested that the physiological immaturity of young leaves may limit the ability of their stomata to open completely, while leaf aging and canopy shading produce increased stomatal resistance within older leaves (Field, 1987). This relationship for peach is supported by the work of Anderson and Brodbeck (1988). If the major role of an antitranspirant is to reduce water loss by increasing stomatal resistance, then a maximum effect may be expected on mature leaves with fully open stomata.

Reports in the literature show antitranspirants improved the water status of treated trees (Davenport et al., 1974b, 1975). In our study there was minimal improvement in peach leaf water potential. Differences in soil water extraction patterns and rooting volume may explain lower-than-expected water potentials in the AT tree. Armstrong and Ligon (1986) have shown that peach trees extracted most of the water in the upper $30 \mathrm{~cm}$ of wet soil, but gradually extended to deeper levels as the soil moisture was depleted. Neutron probe measurements obtained in our study suggest that, during the dry-down cycle, water withdrawal below $1 \mathrm{~m}$ was reduced in the AT tree. Davenport et al. (1973) also alluded to this in their study on oleander, and suggested that reduced root growth at lower depths may ultimately be caused by a reduction in photosynthesis due to the antitranspirant.

The data show the antitranspirant to be effective whether the tree was irrigated or dry. At completion of the dry-down cycle, leaves of both peach trees were wilted, even though transpiration continued to be reduced in the treated tree. Weller and Ferree (1978) and Miller (1979) reported that, although transpiration continued to be reduced in dry antitranspirant-treated apple trees, the treatment did not protect the tree from manifestations of water stress, such as leaf rolling and wilting, once a critical level of soil moisture or $\psi_{\mathrm{L}}$ was reached.

The average size of individual leaves in our experiment was 
not affected by the antitranspirant. Water stress alone has been shown to reduce leaf size in peach (Steinberg, 1988). New leaf and flower bud initiation were also not affected by the antitranspirant. Since peach flower initiation occurs during June and July, application of an antitranspirant during or immediately after this period likely will not affect this process. It is unfortunate that further evaluation of fruit bud development was halted due to frost.

The antitranspirant did not have a significant effect on stem elongation or new leaf production rates. Similarly, Weller and Ferree (1978) reported no change in apple shoot growth within the first month after spraying. Although growth regulation resulting from the antitranspirant has the potential benefit of reducing the amount of wood pruned during the winter, the growth reduction may be small if the antitranspirant is applied during a period when tree growth is already normally slowing. In fact, Larson et al. (1988) found that changes in tree growth due to water stress following harvest were economically insignificant.

Although Davenport et al. (1974a) found that antitranspirants increased short-term vegetative growth in some woody species due to the overriding effect of an improved plant water potential, they allow that eventual long-term growth reductions are likely due to a slower photosynthesis rate and/or depletion of carbohydrate reserves. Antitranspirants could be used to reduce water use in peach following harvest without adversely affecting the next year's production, provided the effect on normal carbohydrate accumulation is minimal. Carbohydrate storage is known to play a role in winter cold hardiness and growth the following spring, yet it is not known to what degree antitranspirants may affect this process. More information is needed on the effect of antitranspirants on tree growth, carbohydrate storage, and yield before they can realistically be used on a commercial basis. However, antitranspirants may also be a useful tool for investigations of photosynthate availability vs. water status control of tree growth.

\section{Literature Cited}

Albrigo, L.G. 1977. Comparison of some antitranspirants on orange trees and fruit. J. Amer. Soc. Hort. Sci. 102:270-273.

Anderson, P.C. and B.V. Brodbeck. 1988. Water relations and net $\mathrm{CO}_{2}$ assimilation of peach leaves of different ages. J. Amer. Soc. Hort. Sci. 113:242-248.

Armstrong, C.F. and J.T. Ligon. 1986. Moisture uptake patterns of nonirrigated and trickle irrigated peach roots. Amer. Sot. Agr. Eng., St. Joseph, Mich. Paper 86-2126.

Chalmers, D. J., K.A. Olsson, and T.R. Jones. 1983. Water relations of peach trees and orchards, p. 197-232. In: T.T. Kozlowski (cd.). Water deficits and plant growth. vol. VII. Academic, New York.

Davenport, D. C., M.A. Fisher, and R.M. Hagan. 1972. Some counteractive effects of antitranspirants. Plant Physiol. 49:722-724.

Davenport, D. C., P.E. Martin, and R.M. Hagan. 1973. Effects of an antitranspirant on water use by highway oleander (Nerium oleander L.) plantings. J. Amer. Soc. Hort. Sci. 98:421-425.

Davenport, D. C., K, Uriu, and R.M. Hagan. 1974a. Effects of film antitranspirants on growth. J. Expt. Bet. 25:410-419.

Davenport, D. C., K. Uriu, and R.M. Hagan. 1974b. Antitranspirants to size peaches and replace preharvest irrigation. HortScience 9:188189.

Davenport, D. C., K. Uriu, and R.M. Hagan. 1975. Antitranspirant effects on the water status of 'Manzanillo' olive trees. J. Amer. Soc. Hort. Sci. 100:618-622.

Davies, W.J. and T.T. Kozlowski. 1974. Short- and long-term effects of antitranspirants on water relations and photosynthesis of woody plants. J. Amer. Soc. Hort. Sci. 99:297-304.

Field, C.B. 1987. Leaf age effects on stomatal conductance, p. 367384. In: E. Zeigler, G.D. Farquhar, and I.R. Cowan (eds.). Stomatal function. Stanford Univ. Press, Stanford, Calif.

Gale, J. and R.M. Hagan. 1966. Plant antitranspirants. Annu. Rev. Plant Physiol. 17:269-282.

Haverkamp, R., M. Vavelin, and G. Vachand. 1984. Error analysis in estimating soil water content from neutron probe measurements: 1. Local standpoint. Soil Sci. 137:78-90.

Jordan, W. R., K. Brown, and J.C. Thomas. 1975. Leaf age as a determinant in stomatal control of water loss from cotton during water stress. Plant Physiol. 56:595-599.

Kramer, P.J. and T.T. Kozlowski. 1979. Physiology of woody plants. Academic, New York.

Larson, K. D., T.M. DeJong, and R.S. Johnson. 1988. Physiological and growth responses of mature peach trees to postharvest water stress. J. Amer. Soc. Hort. Sci. 113:296-300.

McFarland, M. J., J.W. Worthington, and J.S. Newman. 1983. Design, installation and operation of a twin weighing lysimeter for fruit trees. Trans. Amer. Sot. Agr. Eng. 26:1717-1721.

Miller, S. 1979. Effects of preharvest antitranspirant sprays on the size and quality of 'Delicious' apples at harvest. J. Amer. Soc. Hort. Sci. 104:204-207.

Scholander, P. F., H.T. Hammel, E.A. Hemmingsen, and E.D. Bradstreet. 1964. Hydrostatic pressure and osmotic potential of leaves of mangroves and some other plants. Proc. Natl. Acad. Sci. USA 52:119125.

Solarova, J., J. Pospisilova, and B. Slavik. 1981. Gas exchange regulation by changing epidermal conductance with antitranspirants. Photosynthetic 15:365-400.

Steele, R.G.D. and J.H. Torrie. 1980. Principles and procedures of statistics. McGraw Hill, New York.

Steinberg, S.L. 1988. Leaf and whole tree water relations of peach [Prunus persica (L.) Batsch] PhD Diss. Texas A\&M Univ., College Station.

Van Bavel, C.H.M. 1963. Neutron scattering measurement of soil moisture: development and current status. In: Proc. Intl. Symp. Humidity and moisture, 20-23 May. Washington, D.C. vol. 22. p. 171184.

Weller, S.C, and D.C. Ferree. 1978. Effect of a Pinolene-base antitranspirant on fruit growth, net photosynthesis, transpiration, and shoot growth of 'Golden Delicious' apple trees. J. Amer. Soc. Hort. Sci. 103:17-19. 